\title{
National Parks and Other Protected Areas: Some Reflections on the Past and Prescriptions for the Future*
}

\author{
by \\ HAROLD K. EIDSVIK, M.F.(Michigan) \\ Executive Officer, IUCN Commission on National Parks and Protected Areas, International \\ Union for Conservation of Nature and Natural Resources, 1196 Gland, Switzerland; \\ formerly Deputy Chairman, IUCN Commission on National Parks and Protected Areas \\ and Senior Policy Adviser to Parks Canada.
}

\section{INTRODUCTION}

In the latest Spring issue of Environmental Conservation, Guppy (1980) and Goodland (1980) discussed the impact of development on such tribal peoples as the Amerindians of the Amazon, and Goldsmith (1980) reintroduced the concept of the World Ecological Areas Programme (WEAP). At much the same time IUCN (1980a), UNEP, and others, launched the World Conservation Strategy (WCS), which contains three fundamental objectives:

-maintenance of essential ecological processes and lifesupport systems;

- preservation of genetic diversity; and

- sustainable utilization of species and ecosystems.

Each of the above-cited papers suggests a shift in conservation strategy to incorporate broadened social objectives and rural development into future conservation programmes: in brief, conservation with development. The present contribution looks more closely at these concepts in relation to protected areas, following some warnings given in an earlier paper (Polunin \& Eidsvik, 1979).

The recognition of the need for protection of natural resources is not new; for example, China issued forest protection decrees in $1122 \mathrm{BC}$, Poland protected the European Beaver in the 16th Century, and Switzerland protected song-birds in 1535 (Szafer, 1973). What is new is the increasing attention that is being given to the survival of Man as a fundamental benefit arising from the protection and sustained use of living natural resources.

The need to protect areas of outstanding beauty or natural value was given a major impetus with the estab. lishment of the world's first national park-Yellow. stone-in 1872. This was followed by Australia's Royal National Park in 1879 and Canada's Banff National Park in 1885 . By the turn of the century, 20 national parks and similar reserves had been established in various countries (IUCN, 1980b). At that time their principal objective was the protection of Nature; human populations were not a major concern, and nor was the landscape

\footnotetext{
*Based on a paper presented by the Author at the Central and West African Conference on Protected Areas, Ouagadougou, Upper Volta, 5 February 1980.
}

or the fauna and flora within the park managed with a view to sustaining production for Man. Yet in my opinion it is the growing acceptance of the most anthropocentric among these considerations that will have the greatest impact on conservation as we move into the closing decades of this century.

\section{IDENTIFYING SOCIAL RESPONSIBILITY AS A MANAGEMENT OBJECTIVE FOR PROTECTED AREAS}

In a remarkable introduction to the 19.13 'International Conference for the Protection of Nature', Paul Sarasin stressed the need to recognize human rights and to stop what, at that time, was a slaughter of primitive people on most continents of the world. He saw Man as a part of Nature, and he saw the need to protect 'this species' as being of fundamental importance to conservation (Sarasin, 1913). He was speaking as a scientist, and his concern was as fundamental as that for the preservation of genetic material about which we hear so much today.

The International Union for the Protection of Nature (now IUCN ${ }^{\dagger}$ ), meeting at Lake Success in 1949, directed its first resolution to the United Nations, advocating the need for study of 'human ecology' in relation to 'dynamic ecological situations, including all possible factors such as soil, water, food, climate, plants, animals, and the people concerned, with special emphasis on their interrelationships' (UNESCO, 1950). In many ways this could be described as the forerunner of the 'Man and the Biosphere' (MAB, cf. Batisse, 1980) programme. If one considers the basis for setting aside National parks through the 1950s and 1960s, one cannot find a great deal of concern for the interaction between Man and Nature in the national parks that were established during those decades. Generally, a policy of exclusiveness was followed and, in essence, this was called for in the criteria for the establishment of national parks (IUCN, 1970).

Dr Marion Clawson, of Resources for the Future, in addressing the Canadian National Parks 'Today and To-

\footnotetext{
†The name was changed in 1956 to the International Union for Conservation of Nature and Natural Resources, in order to reflect a broader mandate than strictly nature protection.
} 
morrow' Conference in 1968, referred to national parks as 'social institutions'. He said: 'The precise concept of the park and its role and more particularly its management, must be modified, changed, and evolved over a period of time as the economy and the society evolves', continuing 'National parks have always got to be viewed against the background of the broad social structure, the functioning of the economy and of life generally within the country today and as best can be foreseen for, say, a generation ahead' (Clawson, 1969). It is highly unlikely that the 'North American' model of national parks will survive in many countries where a large popular movement does not exist for their protection.

At the Second World Conference on National Parks, Perez Olindo, then Director of the Kenya National Parks Service, said, 'It must be accepted that if conservation of wildlife or any other resource in developing or developed countries is not seen to be within the context of human welfare, and the well-being of the total environment, then the future for such a resource cannot be bright' (Olindo, 1974). The pursuit of Olindo's objective becomes more and more critical as populations increase and energy and other resources come under ever-greater pressures. There is little doubt that 'green areas' - seen as empty open spaces by many people-will come under increasing pressure to satisfy growing demands for the resources of space and energy.

\section{THE RELATIONSHIPS TO PRIMITIVE SOCIETIES}

In 'Planning Human Activities on Protected Natural Ecosystems', Lusigi states that 'The foundation doctrine of Kenyan National Parks was total exclusion of Man, except as a passive sightseer. There was scant regard or respect for the role which tribesmen had played over centuries in the formation of the spectacular game habitat, particularly as predators of large herbivores' (Lusigi, 1978).

The role of tribespeople as manipulators of habitat or predators of large herbivores must be provided for in contemporaty park management or, alternately, other methods must be developed as a substitute. In either event, a sound scientific basis is essential for effective management.

We have made considerable progress in the protection of Nature since 1913, but the insensitivity of which $\mathrm{Dr}$ Sarasin spoke continues even today. 'Will cowboys wipe out Indians? - -anthropologists say that only the creation of a huge single park covering $6,500,000$ ha will allow these interrelated and independent groups to survive' (Anon., 1979a), while '...greater efforts are required to save the last large tribe of unaccultured indians' (Anon., $1979 b$ ). It seems rather fundamental, if we cannot protect our own species from continued assaults on their land in the name of progress, to consider how we can expect to turn back similar future assaults on the land which 'now belongs' to the rhinoceros, the elephant, or the orang-utan. In other words, if Man will not provide for the protection of Man, what hope have we that, in the face of increasing scarcity, he will protect Nature.
The record has not been good: 'Indeed the destruction of the primitive way of life in the name of progress seemed a devastating indictment of industrial society's attitude for Nature, for the environment, and for the phenomenal diversity of human culture' (Bunyard \& Hildyard, 1979). It is in view of this background that we must find better prescriptions for ensuring that conservation programmes go forward in harmony with primitive peoples, and for the benefit of people in general.

Fundamentally, the establishment and management of national parks and protected areas must give consideration to people as a part of the Biosphere in which we all live, and of which people form an integral part. Some of these people may be 'indigenous' and live in protected areas, some may be 'local' and live adjacent to protected areas, and some may be 'tourists' who come to share the benefits of a protected area. In order to attain the objectives of genetic protection and sustained use, we must provide for an array of users. There is an evident need for more research into natural systems and their linkage to the social and economic systems in which we live.

When Norman Myers suggested that 'Ecological requirements of parks must be balanced against socio-economic constraints in their environs' (Myers, 1972), he was looked upon as some kind of a pariah by many conservationists. The dangers of alienating conservation objectives from broader social objectives have since become more evident.

\section{CHANGING TIMES}

A significant break in traditional thought occurred at IUCN's General Assembly in Kinshasa, Zaire, in 1975. A resolution was passed that called on governments to 'devise means by which indigenous people may bring their lands into conservation areas without relinquishing their ownership use or tenure rights' (IUCN, 1976).

One of the first examples of the application of this resolution is found in the Kakadu National Park in Australia's Northern Territory (Gardner \& Nelson, 1980). The lands for the park are leased to the Government by the aboriginal people of the area. A management council has been created which provides for major control by the aboriginal people, who are also being trained to manage the area.

The Biosphere Reserves of Mapimi and Michilia (UNESCO, 1979), in Mexico, are other recent examples of how conservation objectives can be attained by integrating research, education, and protection, into local social and economic systems.

Historically, one cannot overlook the value of the relatively standardized definition of 'National Park' (IUCN, $1980 b$, p. 25) in communicating conservation concepts on a global basis. In the world there are today more than $3,000,000$ square kilometres protected in national parks or equivalent reserves-approximately $2 \%$ of the continental land-mass.

An analysis of the 1980 UN List of National Parks and Equivalent Reserves indicates that, during the past three decades, new national parks and equivalent reserves 
TABLE I. Protected Areas in 1980 UN List.

\begin{tabular}{lc}
\hline Realm & Hectares \\
\hline 1. Nearctic & $109,878,791^{*}$ \\
2. Palaearctic & $29,867,856$ \\
3. Africotropical & $86,482,402$ \\
4. Indomalayan & $18,733,392$ \\
5. Oceanian & 115,862 \\
6. Australian & $28,451,526$ \\
7. Antarctic & $2,562,088^{\dagger}$ \\
8. Neotropical & $35,007,473$ \\
\cline { 2 - 2 } & $311,099,390$ \\
\hline
\end{tabular}

*Includes $70,000,000$ ha in the Greenland National Park.

$\dagger$ Includes New Zealand.

have been created at an accelerating rate. In the 1950 s 100 new areas were identified, in the 1960s 200, and in the 1970s 330 (IUCN, 1980b). This positive trend needs careful analysis because there is no indication of how effectively these areas are managed to achieve conservation objectives. Nor is there any indication that new training schools have been established to provide competent management personnel.

IUCN has been made aware of the devastating impact of armed warfare on habitats and species in national parks. In addition, continued excessive exploitation of wild animals for the pet trade, the biomedical trade, and the zoological gardens trade, is continuing.* For example, the annual trade in crocodiles is in the hundreds of thousands, and frogs killed for science number in the millions (Inskipp \& Wells, 1979).

With such a variety of pressures on natural resources, the need for more and more intensive protection of those resources which are currently found in national parks and equivalent reserves is all-too evident. The manpower and financial resources which are needed for the protection of the $2 \%$ of the Earth's terrestrial surface that are currently in protected areas are far from adequate. Can we rest with any confidence that the $98 \%$ of the globe which is not covered by the UN List of National Parks and Equivalent Reserves is adequately managed?

It is evident to the writer that protected areas are but one mechanism for attaining conservation objectives. They are an important mechanism but in themselves they are inadequate.

\section{WORLD CONSERVATION STRATEGY}

An indicator of change as well as a guide to change that must come if we are to sustain our population and natural resources, is the World Conservation Strategy (WCS). The complexity of the conservation problem can be summed up as follows: 'Living resource conservation is just one of a number of conditions necessary to assure human survival and well-being, and a world conservation strategy is but one of a number of strategies needed: a strategy for peace; a strategy for a new international economic order; a strategy for human rights; a strategy for

\footnotetext{
*Much the same must apply to the widespread gathering of wild plants for horticultural, medicinal, and herbarium, purposes.-Ed.
}

overcoming poverty; a world food-supply strategy; a population strategy. Several of these issues are properly the subject of the International Development Strategy for the Third United Nations Development Decade. All such strategies should be mutually reinforcing'. (IUCN, 1980a).

The WCS stresses that 'The integration of conservation and development is particularly important, because unless patterns of development that also conserve living resources are widely adopted, it will become impossible to meet the needs of today without foreclosing the achievements of tomorrow'.

The Strategy goes on to say, 'Conservation and development have so seldom been combined that they often appear-and are sometimes represented as being-incompatible. Conservationists themselves have helpedquite unwittingly - to foster this misconception. Too often they have allowed themselves to be seen as resisting all development-although often they have been forced into that posture because they have not been invited to participate in the development process early enough. The result has been not to stop development, but to persuade many development practitioners, especially in developing countries, that conservation is not merely irrelevant, it is harmful and anti-social. Consequently, development has continued unimpeded by conservationists, yet with the seeds of its eventual failure lying in the ecological damage that conservation could have helped to prevent'.

There is a great need for recognition of the fact that conservation can be achieved along with development. This is the philosophy expounded in the Strategy, which is, in itself, evidence of the considerable change that has taken place in conservationists' thinking in the past few years. It is also clear that many other approaches must be utilized to attain conservation objectives-for example, conventions such as the Convention on International Trade in Endangered Species of Fauna and Flora of 1973, and the Migratory Species Convention of 1979.

The next section of this paper suggests several approaches - primarily related to the concept of protected areas as a tool or means by which we can attain conservation objectives.

\section{NEW DIRECTIONS?}

What changes in past practices are indicated if we wish to reach a closer accord between parks as isolated islands and parks as a powerful contributor to Man's social and economic welfare-in the short term as well as the long term, for local people as well as tourists, and for plants as well as animals? What can be done to resolve conflicts and reduce tensions between the park manager and his neighbours living on the periphery of a protected area from which they have been excluded - and of which they may have only a limited perception of the value of the area to society.

A first prescription involves recognition of the fact that the traditional concept of a national park is not the only methanism available. This means that park managers who have been applying one tool, namely 'the national 
park', must carefully reassess the objectives of future conservation action against a range of alternative means for achieving such action. The same prescription must be applied by research officers, wildlife biologists, public servants, and private conservationists, who are all involved in the establishment of protected areas. Table II (IUCN, 1978) illustrates the types of administrative tools which are available. They range from strict nature reserves for the protection of plants, or animals, through national parks, multiple-use areas, and World Heritage sites. It is unlikely that change will occur unless it is encouraged by the individuals who are most closely involved. Park managers must reach beyond their boundaries in both a physical and an administrative sense, to implement these new conservation techniques.

TABLE II. Categories of Conservation Areas.

\begin{tabular}{|c|c|}
\hline \multicolumn{2}{|l|}{ Group A } \\
\hline Category I & Scientific Reserve/Strict Nature Reserve \\
\hline Category II & National Park/Equivalent Reserve \\
\hline Category III & $\begin{array}{l}\text { Natural Monument/National Landmark } \\
\text { Reserve/Wildlife Sanctuary }\end{array}$ \\
\hline Category IV & Nature Conservation Reserve/Managed \\
\hline Category V & $\begin{array}{l}\text { Nature Reserve/Wildife } \begin{array}{c}\text { Sanctuary } \\
\text { Cultural Landscape/Heritage Landscape }\end{array}\end{array}$ \\
\hline Group B & \\
\hline Category VI & Resource Reserve \\
\hline Category VII & $\begin{array}{l}\text { Natural Biotic Area/Anthropological } \\
\text { Reserve }\end{array}$ \\
\hline Category VIII & $\begin{array}{l}\text { Multiple-use Management Area/Managed- } \\
\text { resource Area }\end{array}$ \\
\hline
\end{tabular}

Group C

Biosphere Reserve World Heritage Site (Natural)

Our second prescription requires detailed objectives for each category of protected area established. According to Lusigi (1978), this could provide for Conservation Unit Objectives which attain the goal of conservationwith-development as follows:

1. Conservation of the wildlife populations.

2. Enhancement of the lives of the people of the area through ' coordinated development of both wildlife and livestock in the surrounding area.

3. Development of tourism in the area for both national and local economic development.

4. Provision of a suitable environment for education of the younger generation and the public at large.

5. Provision of a suitable environment where the dynamics of the ecosystem can be observed and studied scientifically.

6. Provision of an ecologically healthy environment, free from deterioration, where all these activities can be realized.

It is evident that, to the achievement of Lusigi's objectives, we must also add those of the WCS: the maintenance of ecological processes and life-support systems, the protection of the habitat of utilized species, and the on-site protection of genetic resources.

In addition to the conservation unit, Lusigi (1978) recommends a surrounding buffer or multiple-use management unit with the following cultural, touristic, and wildlife, management benefits or objectives:
1. Unique wildlife populations, habitat types, or scenic features, would be preserved.

2. The portions designated as parks would retain a wilderness atmosphere without being isolated.

3. Migratory wildlife populations would be maintained as their ranges inside and outside the park would be controlled.

4. Wildlife populations would be managed to prevent one species from dominating the park or the rest of the ecosystem. Wildlife populations could be harvested outside the park with little or no cropping taking place in the park. It may be necessary to cull surplus animals to protect the habitat from destruction.

5. Cultural harmony would be restored between the people and wildlife, as the former would be involved in the management of the latter and their life-style would not be disturbed through unnecessary prohibition. Only the livestock numbers would be controlled, but no difficulty is foreseen in this as wildlife populations would also be controlled.

6. Economic benefits would be provided to the local residents through:

a) Tourism-wages to tour-bus drivers and tour guides, hotel personnel, game guards, administrative staff, etc.

b) Game cropping-wages to skinners, field staff, tanners, meat processors, etc., income from sales of meat and raw hides or live animals.

c) Income from sale of souvenirs made from animal products and sale of live animals for restocking.

7. Safari hunting would be controlled by the community, and income from concession fees, trophy fees, and meat sales, would accrue to the community. Wages for operators would reduce unemployment for the communities.

The approach suggested by Lusigi would undoubtedly cause concern among more traditionally-minded preservationists, but it is suggested here as an illustration of the type of consideration which must be given if future conservation action is to meet Olindo's goal of placing conservation 'within the context of human welfare and the well-being of the total environment'.

In many countries that may consider bringing about such changes, the approach suggested by Lusigi would require a major review of legislation and national conservation policies, as areas protected through 'social invention' cannot exist outside appropriate political systems, and conservationists cannot achieve their goals without working through political mechanisms. There is ample evidence that dedicated public servants, working in harmony with non-governmental organizations and in concert with political mechanisms, can bring about dramatic changes in national policies. Examples of this type of action include implementation of the programmes of Roosevelt (USA in 1906), Oduber (Costa Rica in the 1970s), Perez (Venezuela in the 1970s), Chretian (Canada in the 1970s), and Carter (USA in 1978).

The World Conservation Strategy, which was launched in 34 countries in March 1980, provides a philosophical 
base and a guideline for the development of national and regional action plans. It is evident that, with only $2 \%$ of the Earth's surface 'protected', much effort must be concentrated on expanding the protection element and integrating it with development as recommended in the Strategy and more specifically in this paper.

An additional prescription is needed to overcome a major problem to which many countries may be sensitive - a problem which is resulting in the decimation of wildlife, the destruction of habitat, and the loss of much of the infrastructure in some of our national parks. This is the turmoil of civil strife and actual war. We are all aware of the problem - but is there nothing we can do?

The concept of 'open towns' which 'were not defended' has existed since 1874 - only two years after the world's first national park was established. Angor Wat in Cambodia, an outstanding cultural and religious site which is also a national park, was not devastated during at least one previous war, though at the time of writing this approach appears less hopeful than it did. Should conservationists seek the extension of the Hague Convention ('Final Act of the Intergovernmental Conference on the Protection of Cultural Property in the Event of Armed Conflict', cf. UNESCO, 1954) to areas of our natural heritage? I do not wish to appear naïve, but some resolution or reduction of military pressures on natural areas would do more for the conservation of 'Man and Nature' than dozens of new national parks. At a minimum level of action, bringing the existence of critical conservation areas to the attention of military leaders may save them from 'accidental' destruction.

\section{FINANCING THE WORLD HERITAGE}

As a final presciption, one cannot consider conserving the global heritage without having some means of financing the necessary activities. The World Heritage Convention (UNESCO, 1972) includes provisions for a 'World Heritage Fund' from which funds for conservation have been provided for World Heritage Sites such as the Galápagos National Park and the Ngorongoro Conservation Area. Projects are under way for Virunga, Simien, and Sagarmatha. The fund, however, is small - about 1 million US $\$$ - and the task is huge, particularly when both cultural and natural areas are included.

Has the time come for a more concerted fund-raising effort? 'The establishment of preserves in some of the less-developed countries may conflict with other economic development opportunities. In such cases, the world as a whole may wish to help defray the costs of protection and wish to contribute in other ways to better management and proper use of such areas as a means toward the economic growth of such countries' (Train, 1974). This is being done to some extent by the World Wildlife Fund, UNEP, UNESCO, and some AID programmes, but the need is many times greater than the resources that are available. The integration of conservation with development is one mechanism for bringing conservation into the mainstream of development financing.

\section{INDUSTRIAL RESPONSIBILITY}

The World Conservation Strategy (IUCN, 1980a) stresses the responsibility of industry to finance the protection of in situ genetic resources which are essential to plant breeders and seed suppliers. The Strategy also sug. gests that industries and commercial users who depend on naturally occurring raw materials should sponsor the establishment and maintenance of protected areas for the preservation of representative and unique ecosystems as potential product-banks. Examples of this kind of action can be found in Indonesia, where the forest industry is financing the establishment of a national park, and in Nicaragua, where the Regional Development Bank has made a large loan to the National Parks Authority to finance the infrastructure required in the development of a national park. Actions such as these indicate a positive trend towards adequate financing for conservation needs.

Should the 'World Heritage Fund', which is now restricted to World Heritage Sites, be expanded and given a broader mandate? Should a 'World Heritage Foundation' be established to include cultural as well as natural areas and thus incorporate the 'World Heritage Fund'? Should the Board of Directors include representatives of the 'World Heritage Committee', the World and Regional Banks, and AID organizations? Could such a foundation become the depository of funds originating as a result of a more rigorous approach to natural-resource-using industries? The management of the Foundation could be carried out by IUCN and the International Commission on Monuments and Sites (ICOMOS), with the fund-raising programmed in cooperation with the World Wildlife Fund.

Such a 'World Heritage Foundation' would deal with the past, the present, and the future, and would provide a broad social and economic base for ensuring the financing of the conservation of our global heritage. There is urgent need for this greatly increased financing, for improved organization, and for more effective distribution of resources. It is a challenge for the World Heritage Committee, UNESCO, IUCN, and the World Wildlife Fund.

\section{ACKNOWLEDGEMENTS}

The writer would like to thank Messrs Robert Allen, John Kundaeli, and Adrian Phillips, all of IUCN, for reviewing and commenting on earlier drafts of this paper which was presented in substance at the Central and West African Conference on Protected Areas, Ouagadougou, Upper Volta, on 5 February 1980.

\section{SUMMARY}

The World Conservation Strategy stresses the maintenance of essential ecological processes and life-support systems, preservation of genetic diversity, and sustainable use of species and ecosystems - in brief, the integration of conservation with development. The present 
paper traces shifts in conservation policy, which originnally saw national parks as islands isolated from their surrounding communities, through to the evolving concept of protected areas integrated with development programmes. It stresses the need for protected areas, and notes that only about $2 \%$ of the world's continental land-mass can be so classified. It is thereofre imperative for the survival of Nature and Man that a closer linkage be established between protection and development functions in such a way that both are seen as essential from a social and economic viewpoint.

The continuing exploitive pressures on living natural resources are noted, and suggestions are made towards mitigating the impact of armed conflict and increasing financing for protected areas in order to achieve conservation and development objectives.

\section{REFERENCES}

ANON. (1979a). Will cowboys wipe Indians out? International Economist [not available for checking] .

ANON. (1979b). International Herald Tribune, 29 November 1979.

BATISSE, Michel (1980). The relevance of MAB. Environmental Conservation, 7(3), pp. 179-84, fig.

BUNYARD, P. \& HILDYARD, N. (1979). Ten years of survival. The Ecologist, No. 4-5, pp. 168-70.

CLAWSON, M. (1969). The development of recreation in the United States and Canada and its implications for the national parks. Pp. 53-65 and 155 in The Canadian National Parks: Today and Tomorrow (Ed. J. G. Nelson \& R. C. (Scace). University of Calgary and National and Provincial Parks Association of Canada, Calgary, Alberta: $x i+v+$ $1027 \mathrm{pp}$.

GARDNER, J. E. \& NELSON, J. G. (1980). Comparing national park and related reserve policy in hinterland areas: Alaska, Northern Canada, and Northern Australia. Environmental Conservation, 7(1), pp. 43-50, 3 figs.

GOLDSMITH, Edward (1980). World Ecological Areas Programme (WEAP): A proposal. Environmental Conservation, 7(1), pp. 27-9.

GOODLAND, Robert J. A. (1980). Environmental ranking of Amazonian development projects in Brazil. Environmental Conservation, 7(1), pp. 9-26, 2 figs.

GUPPY, Nicholas G. L. (1980). Some crucial issues of our time. Environmental Conservation, 7(1), pp. 3-8.

INSKIPP, T. \& WELLS, S. (1979). International Trade in Wildlife. Earthscan Publications, London, UK: 104 pp.

IUCN (1970). Resolution No. 1: Definition of National Park. P. 156 in Proceedings 10th General Assembly, New Delhi,
India, 1969. IUCN Publications New Series No. 27, [1196 Gland,] Switzerland: $224 \mathrm{pp}$.

IUCN (1971). UN List of National Parks and Equivalent Reserves, 2nd edn. Hayez, rue Fin 4-B, 1080 Brussels, Belgium: 601 pp., maps.

IUCN (1976). Resolution No. 5: Protection of Traditional Ways of Life. Proceedings 12th General Assembly, Kinshasa, Zaire, 1975. IUCN Publications New Series No 44-E, [1196 Gland, Switzerland, 297 pp.

IUCN (1978). Categories, Objectives, and Criteria, for Protected Areas IUCN, [1196 Gland,] Switzerland: $26 \mathrm{pp}$.

IUCN (1980a). World Conservation Strategy. IUCN, 1196 Gland, Switzerland: $x i v+48$ pp. + map section of xviii pp.

IUCN (1980b). United Nations List of National Park and Equivalent Reserves. IUCN, 1196 Gland, Switzerland: $\mathrm{iii}+121 \mathrm{pp}$.

LUSIGI, W. J. (1978). Planning Human Activities on Protected Natural Ecosystems. J. Cramer, Fl-9490 Vaduz, Liechtenstein, vi + 233 pp., illustr. [cf. pp. 198-201] .

MYERS, N. (1972). National parks in savannah Africa. Science, 178, pp. 1255-63.

OLINDO, Perez M. (1974). Park values, changes and problems in developing countries. Pp. 52-60 in Second World Conference on National Parks (Ed. Sir Hugh Elliott). IUCN, [1196, Gland,] Switzerland: 504 pp., illustr.

POLUNIN, Nicholas \& EIDSVIK, Harold K. (1979). Ecological principles for the establishment and management of national parks and equivalent reserves. Environmental Conservation, 6(1), pp. 21-6, 2 figs.

SARASIN, P. (1913). Exposé introductif de M. Paul Sarasin. Pp. 23-82 in Recueil des procès-verbaux de la Conférence Internationale pour la Protection de la Nature. K. J. Wyss, Berne, Switzerland: $247 \mathrm{pp}$., illustr.

SZAFER, W. (1973). History of Nature Conservation in the world and in Poland. Pp. 7-51. Protection on Man's Natural Environment (Ed. Wlodzimierz Michajlow). PWNPolish Scientific Publishers, Warsaw, Poland: 663 pp., illustr.

TRAJN, R. E. (1974). An idea whose time has come: The World Heritage Trust, a world need and a world opportunity. Pp. 377-81 in Second World Conference on National Parks (Ed. Sir Hugh Elliott). IUCN, [1196 Gland,] Switzerland: $504 \mathrm{pp}$, illustr.

UNESCO (1950). Resolution No. 1: Human Ecological Principles. P. 177 in Proceedings and Papers, International Technical Conference on the Protection of Nature, Lake Success, 1949. Hayez, [rue Fin 4-B, 1080 Brussels,] Belgium: xi + $583 \mathrm{pp}$.

UNESCO (1954). Final Act of the Intergovernmental Conference on the Protection of Cultural Property in the Event of Armed Conflict. [The Hague, 1954.] UNESCO, Pl. de Fontenoy, Paris, France: 83 pp. [not available for checking].

UNESCO (1972). Convention Concerning the Protection of the World Cultural and Natural Heritage. UNESCO, Pl. de Fontenoy, Paris, France: $56 \mathrm{pp}$.

UNESCO (1979). Programme on Man and the Biosphere (MAB) Biosphere Reserves, compilation 1, May 1979. UNESCO, P1. de Fontenoy, Paris, France: 156 pp.

\section{Mono Lake, California: Saving a Lake or Serving a City?}

Proposals for the use of water in the American West invariably generate controversy. The crucial elements in most of these disputes are the questions of which individuals or groups should be benefited and which societal purposes should be served. Almost always the most vituperative dialogues involve the contrary philosophies of landscape development and landscape preservation. Several misconceptions tend to constrain innovation in the resolution of such controversies: a belief that the volumes of water used for specific purposes in the past were unalterably 'normal', a failure to appreciate the great variation in water volumes used by differing water users (e.g. farmers or urban populations), and an assumption that existing allocations of water are the best ones possible. This characterization of water resource problems is well illustrated by the controversy arising from the export of water from the Mono Lake Basin in east-central California by the City of Los Angeles.

South-coastal California, from Los Angeles to San Diego, has only limited local water supplies that are far too small for the population of 11 million people. Most of the water imported to the cities of this region 